\title{
Optimasi Perhitungan Jarak antara Kendaraan
}

\author{
Nurul Fathanah Mustamin ${ }^{1 *}$, Indrabayu ${ }^{2}$, Intan Sari Areni ${ }^{1}$ \\ ${ }^{1}$ Departemen Teknik Elektro, Fakultas Teknik, Universitas Hasanuddin, Makassar \\ ${ }^{2}$ Departemen Teknik Informatika, Fakultas Teknik, Universitas Hasanuddin, Makassar \\ J1. Poros Malino km. 6, Bontomarannu, Kabupaten Gowa, Sulawesi Selatan 92171 \\ *Email: nurul.fathanah.576@gmail.com
}

DOI: 10.25042/jpe.112018.02

\begin{abstract}
Abstrak
Penelitian ini bertujuan untuk merancang sebuah sistem estimasi jarak relatif antara kendaraan sebagai penelitian awal untuk konsep pengemudi tanpa awak agar berkendara dengan aman dan terhindar dari tabrakan. Sistem deteksi ini terdiri atas tahap deteksi dengan metode Histogram of Oriented Gradients (HOG) dan tahap estimasi jarak antara kendaraan dengan metode Width Based. Kendaraan yang digunakan pada penelitian ini adalah jenis city car dan van. Hasil deteksi kendaraan untuk jenis city car diperoleh persentase rata-rata TPR (True Positive Rate) sebesar 92\% sedangkan mobil jenis van mendapatkan persentase rata-rata TPR sebesar 64\% untuk 5 video yang di uji. Untuk hasil estimasi jarak relatif antara kendaraan diperoleh untuk jenis mobil city car menunjukkan hasil yang lebih baik dengan nilai MSE 0,29 dan untuk mobil jenis van dengan nilai MSE 0,55.
\end{abstract}

\begin{abstract}
Optimization of Distance Calculation between Vehicles. This study aims to design a system of estimated relative distance between vehicles as initial research for the concept of unmanned drivers to drive safely and avoid collisions. This system consists of vehicle detection phase with Histogram of Oriented Gradients (HOG) method and distance estimation phase between vehicles with Width Based method. Vehicles used in this study are the type of city car and van. The result of vehicle detection for the city car obtained the average percentage of TPR (True Positive Rate) of 92\% while the van type get an average percentage of TPR of $64 \%$ for 5 videos tested. To estimation result of relative distance, city car shows better result with value of MSE 0.29 and for van type with MSE of 0.55 .
\end{abstract}

Kata Kunci: HOG, MSE, TPR, unmanned drivers, width based,

\section{Pendahuluan}

Perkembangan industri otomotif di Indonesia menunjukkan peningkatan yang signifikan setiap tahunnya. Posisinya bahkan menjadi tulang punggung pemerintah dalam mewujudkan target pertumbuhan industri sebesar 5,67\% bersama dengan sektor industri elektronik, kimia farmasi, serta makanan dan minuman $[1,2]$.

Perkembangan ini sejalan dengan meningkatnya teknologi otomotif yang disebut dengan connected cars menjadi sebuah trend baru, dimana teknologi seperti kendaraan digital dengan $W i-F i$, sistem infotainment yang canggih dengan aplikasi ponsel, komunikasi kendaraan-kekendaraan (vehicle-to-vehicle) yang memungkinkan mobil untuk berkomunikasi satu sama lain di jalanan. Mobil dengan sistem cerdas ini mengalir dari ruang desain ke aplikasi di jalan.
Kendaraan otonom (autonomous vehicle) juga merupakan salah satu fitur penting masa depan bagi industri otomotif [3].

Industri otomotif telah lama berinvestasi dalam pengembangan sistem otonom yang membuat kendaraan mengemudi sendiri dan meminimalkan campur tangan manusia (manless). Dalam proses pembangunan tersebut, antilock brakes, auto-parking systems, transmisi gigi otomatis, distance warning dan cruise control diperkenalkan sebagai prekursor dari sistem otonom dan sekarang diadopsi sebagai Advanced Driver Assistance System (ADAS) [4].

Kolaborasi industri otomotif dan akademis dalam pengembangan sistem mengemudi secara otomatis juga telah dimulai. Sebagai contoh, Google telah berhasil menguji mobil otonomnya, sementara Ford, MIT, dan Stanford University 
telah bekerja sama untuk meningkatkan kecerdasan sistem mengemudi tanpa awak. Sistem driverless tersebut dirancang untuk menawarkan pengalaman berkendara yang lebih menyenangkan dan nyaman dengan mengurangi input dan usaha manusia yang tidak perlu. Mobil Google ini dilengkapi dengan beberapa sensor seperti kamera, lasers, gps, radars dan wheel encoders [5-7].

Mobil otonom Google atau lebih dikenal dengan Waymo sudah berhasil di uji di jalanan. Tetapi, ada beberapa keterbatasan dalam hal sensornya. Pada tanggal 28 agustus 2014 dilaporkan bahwa prototipe terbaru Google belum diuji dalam hujan lebat atau salju karena masalah keamanan. Kendaraan mengalami kesulitan mengidentifikasi benda-benda, seperti sampah dan puing-puing kecil, sehingga menyebabkan kendaraan berbelok yang tidak perlu. Selain itu, teknologi LIDAR tidak dapat menemukan jalan berlubang atau melihat manusia, seperti seorang petugas polisi, memberi sinyal kepada mobil untuk berhenti $[8,9]$.

Penggunaan sensor aktif memberikan hasil yang sangat baik untuk mendeteksi kendaraan, tetapi selain harganya yang mahal untuk beberapa tipe sensor, juga akan menghadapi kesulitan seperti gangguan sensor saat beberapa mobil menggunakan teknologi yang sama. Sensor pasif atau yang lebih dikenal dengan sebutan Vision Based Sensor seperti kamera memperoleh data tanpa memancarkan sinyal atau tanpa mengganggu kendaraan lain. Sensor pasif dapat menggunakan kamera tunggal, kamera stereo atau beberapa kamera $[10,11]$.

Ada dua langkah yang harus dilakukan untuk dapat mengetahui jarak antara kendaraan dengan menggunakan kamera. Langkah pertama adalah mendeteksi dan melacak letak kendaraan yang berada di depan. Kemudian langkah selanjutnya memperkirakan jarak antara kendaraan. Penelitan untuk estimasi jarak antara kendaraan telah dilakukan oleh penulis pada tahun 2017 namun uji coba dilakukan hanya dengan satu jenis mobil saja, yaitu jenis van. Hasil penelitian menunjukkan rata-rata persentase TPR sebesar $75 \%$ dan $47 \%$ dengan nilai MSE 0,33 [12].
Oleh karena itu, pada penelitian ini diuraikan hasil estimasi jarak antara kendaraan dengan menggunakan dua jenis kendaraan, yaitu city car dan van. Adapun metode yang digunakan yaitu metode Histogram of Oriented Gradients (HOG) untuk tahap deteksi kendaraan dan metode width based untuk estimasi jarak antar kendaraan.

\section{Materi dan Metode}

\subsection{Data Sampel}

Data masukan pada penelitian ini berupa video hasil rekaman kamera dengan spesifikasi 12 megapixel (720x1280). Data video dibagi menjadi data latih dan data uji. Data latih yang digunakan berjumlah 2831 sampel positif dan 5470 untuk sampel negatif. Sedangka untuk data uji digunakan 10 data video berdurasi 5 detik dengan total frame sebanyak 1500.

Gambar 1 memperlihatkan contoh jenis sampel positif dan sampel negative yang merupakan data latih.

\subsection{Metode Deteksi Kendaraan}

Metode deteksi kendaraan yang digunakan pada penelitian ini yaitu metode Histogram of Oriented Gradients (HOG) untuk mengekstraksi fitur pada obyek gambar mobil. Gambar 3 memperlihatkan contoh fitur HOG pada deteksi mobil. Histogram of Oriented Gradients adalah algoritma yang digunakan untuk mengekstraksi fitur pada obyek gambar. Berdasarkan langkahnya, proses awal pada metode HOG adalah mengkonversi citra RGB (Red, Green, Blue) menjadi grayscale, yang kemudian dilanjutkan dengan menghitung nilai gradien setiap piksel. Setelah mendapatkan nilai gradien, maka proses selanjutnya yaitu menentukan jumlah bin orientasi yang akan digunakan dalam pembuatan histogram. Proses ini disebut spatial orientation binning. Namun sebelumnya pada proses gradient compute gambar pelatihan dibagi menjadi beberapa cell dan dikelompokkan menjadi ukuran lebih besar yang dinamakan block. Sedangkan pada proses normalisasi block digunakan perhitungan geometri R-HOG. Proses ini dilakukan karena terdapat block yang saling tumpang tindih. Berbeda dengan proses pembuatan histogram citra 
yang menggunakan nilai-nilai intensitas piksel dari suatu citra atau bagian tertentu dari citra untuk pembuatan histogramnya $[13,14]$.
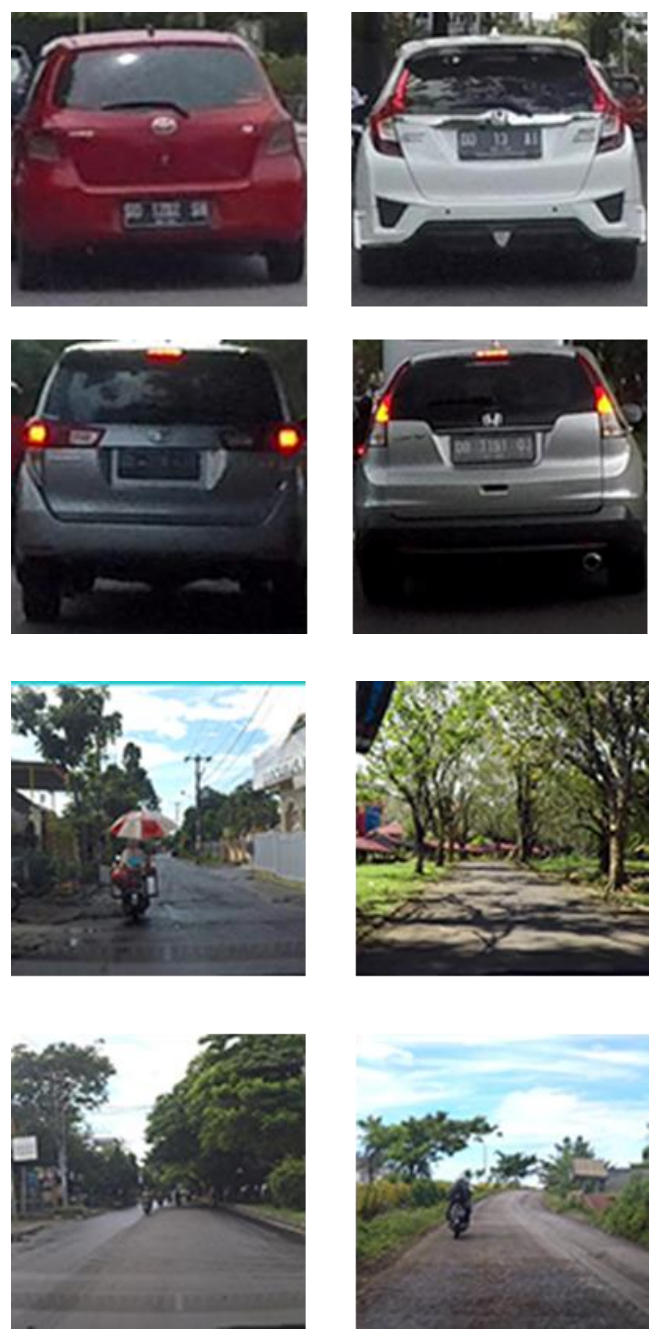

Gambar 1. Sampel positif mobil jenis city car dan van; Sampel negatif objek selain mobil

\subsection{Metode Width Based}

Ilustrasi sistem estimasi jarak berdasarkan lebar kendaraan diperlihatkan pada Gambar 3. Dari Gambar 3 dapat diketahui bahwa, $W$ merupakan lebar kendaraan sebenarnya, $D$ adalah jarak dari kamera ke kendaraan sebenarnya, $p$ merupakan lebar kendaraan dalam pixel dan $F$ merupakan panjang fokal pada ruang pixel yang dapat diperoleh dengan persamaan berikut [15].
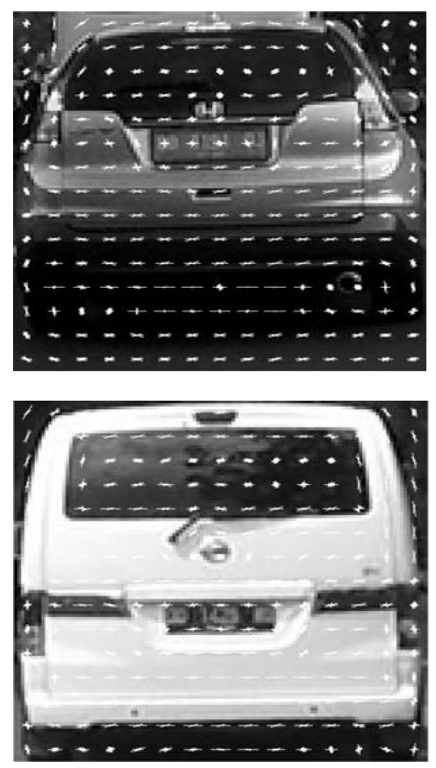

Gambar 2. Fitur HOG pada deteksi mobil

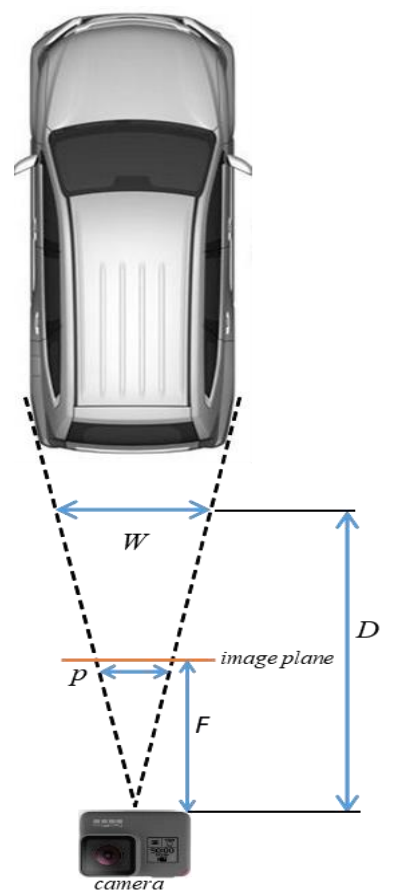

Gambar 3. Sistem estimasi jarak menggunakan lebar kendaraan

$$
F=\frac{(p \times D)}{W}
$$

Setelah nilai $F$ didapatkan maka estimasi jarak antar kendaraan $\left(D^{\prime}\right)$ dapat dihitung dengan menggunakan rumus: 


$$
D^{\prime}=\frac{(W \times F)}{p}
$$

\subsection{Metode Validasi}

Untuk mengetahui unjuk kerja dari sistem yang dibuat, ada dua parameter yang digunakan, yaitu True Positive Rate (TPR) untuk deteksi kendaraan dan Mean Squared Error (MSE) untuk estimasi jarak antara kendaraan. TPR atau dikenal dengan sensitivity diperoleh berdasarkan Confusion Matrix pada Gambar 4. TPR dapat dihitung dengan menggunakan persamaan berikut [16].

$$
T R P=\frac{T P}{T P+F N}
$$

dimana TP (True Positive) merupakan bounding box pada objek kendaraan, FN (False Negative) merupakan merupakan objek kendaraan yang tidak di bounding box.

Sedangkan untuk nilai MSE diperoleh berdasarkan persamaan berikut [17].

$$
M S E=\frac{\sum_{t=1}^{n} e_{t}^{2}}{n}
$$

dimana $n$ adalah jumlah data, $e_{t}$ adalah jumlah error pada nilai $x_{t}-x_{t}, x_{t}$ merupakan nilai aktual sedangkan $x_{t}$, merupakan nilai hasil estimasi. Nilai MSE dikatakan baik digunakan ketika hasil error yang didapatkan sangat rendah atau mencapai nilai 0 [17].

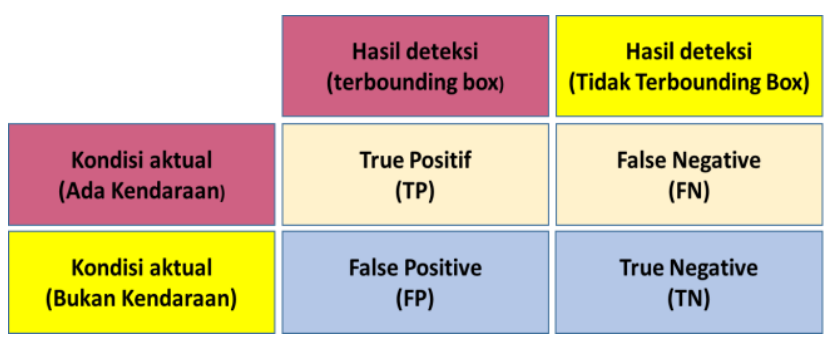

Gambar 4. Confusion matrix

\subsection{Rancangan Sistem}

Perancangan sistem yang dilakukan pada penelitian ini, dapat dilihat pada Gambar 7 . Tahapan-tahapan yang dilakukan untuk membuat sistem deteksi kendaraan dan estimasi jarak dijelaskan sebagai berikut:
- Input video

Input data berupa video yang telah diambil pada tahap pengumpulan data. Skenario pengambilan data diperlihatkan pada Gambar Penelitian ini menggunakan video berformat mp4 dengan ukuran frame $720 \times 1280$ piksel. Frame rate untuk tiap video menggunakan $30 \mathrm{fps}$. Durasi video yang digunakan untuk pengujian sistem adalah 5 detik untuk semua video.

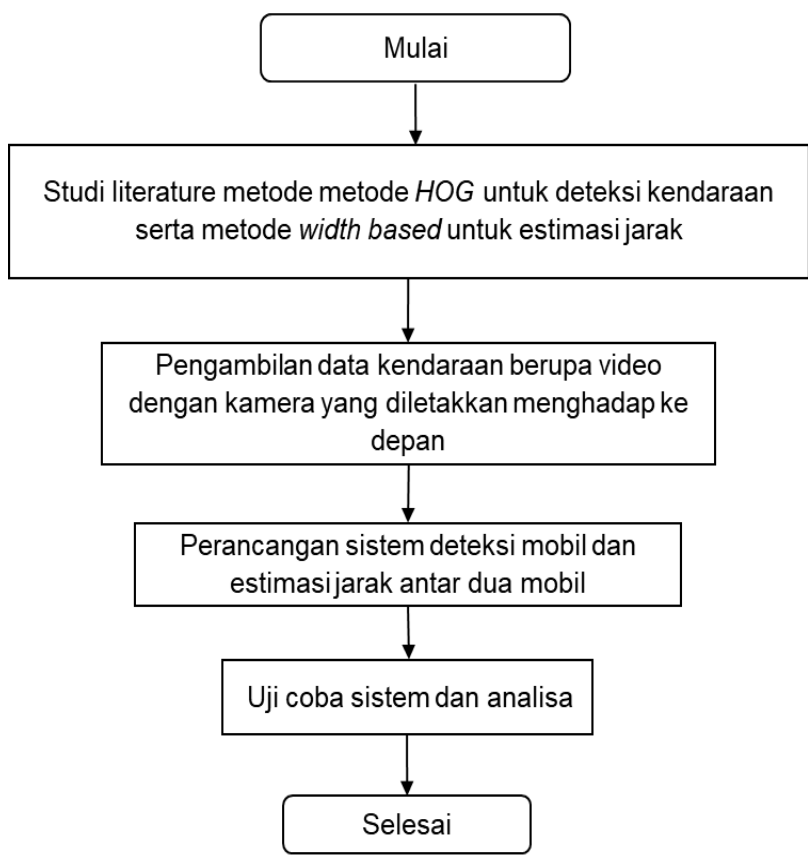

Gambar 5. Tahapan-tahapan penelitian

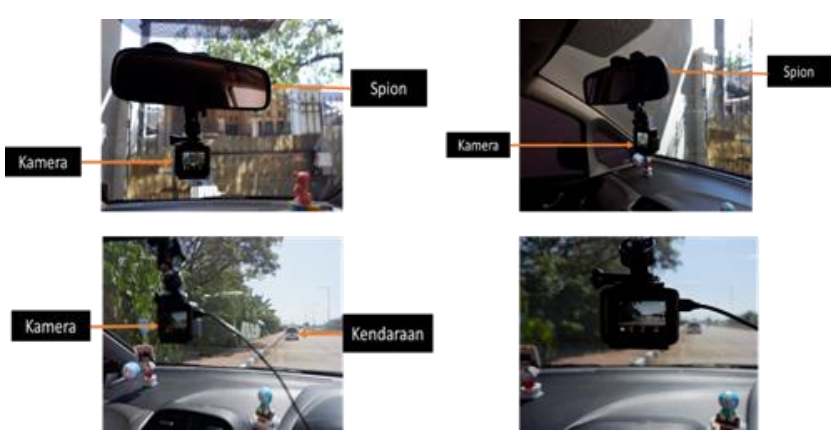

Gambar 6. Teknik pengambilan data

- Ekstrak Frame

Hasil video rekaman di ekstrak dalam bentuk frame yang menjadi masukan pada aplikasi Training Image Labeler pada Matlab R2016b. Pada tahap ini hanya dipilih frame yang memiliki objek kendaraan di dalamnya. Sedangkan frame yang tidak memiliki objek kendaraan akan di 
masukkan ke dalam folder data sampel negatif. Contoh ekstrak frame dapat dilihat pada Gambar 8.

- Pemilihan Region of Interest (ROI)

Pemilihan ROI dilakukan pada objek yang dinyatakan positif sebagai kendaraan. Objek ini nantinya akan di simpan dan dijadikan sebagai sampel positif kendaraan. Jenis kendaraan yang digunakan untuk sampel positif adalah mobil kecil dan mobil besar dalam penelitian ini disebut dengan city car dan van. Proses pemilihan ROI pada aplikasi matlab dapat dilihat pada Gambar 9.

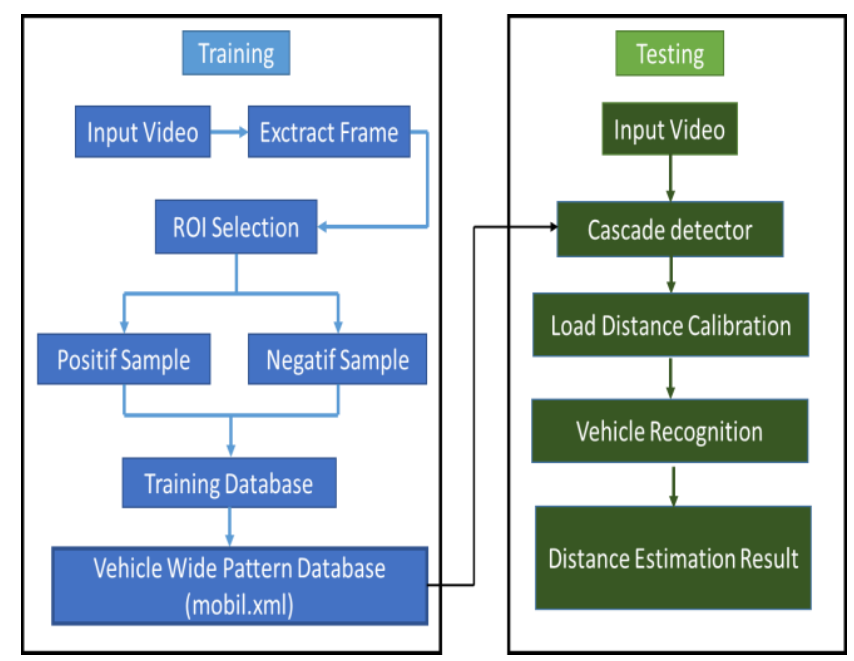

Gambar 7. Desain sistem deteksi dan estimasi jarak relatif antara kendaraan

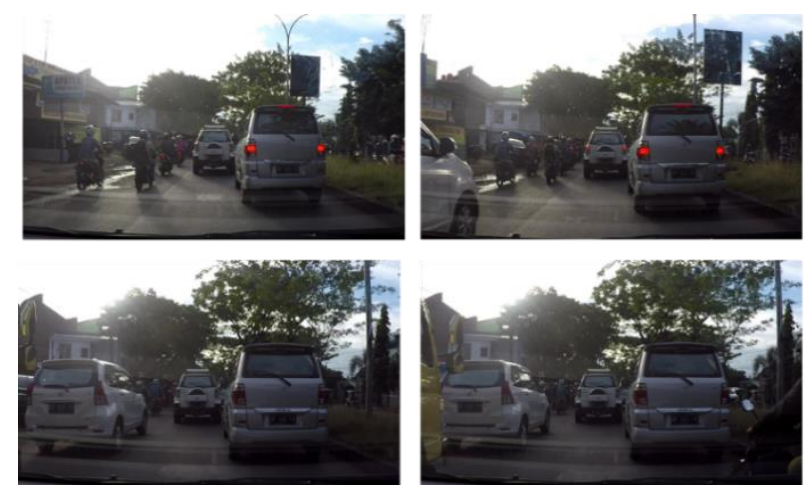

Gambar 8. Contoh ekstrak frame

- Sampel Positif dan Sampel Negatif

Sampel positif merupakan hasil dari pemilihan ROI pada ekstrak frame rekaman video. Hasil dari ROI tersebut di export ke dalam bentuk tabel. Tabel ini akan memuat informasi mengenai nama frame serta alamat pemilihan ROI dalam piksel frame. Kemudian hasil dari tabel ini akan disimpan dengan ekstensi .mat pada matlab.
Sedangkan sampel negatif merupakan data frame hasil rekaman video yang memuat sembarang pola selain objek kendaraan. Data sampel negatif dibutuhkan untuk pelatihan sistem cascade classifier.

\section{- Training Database}

Pada tahap ini dilakukan training pada sampel positif dan sampel negatif dengan langkah sebagai berikut:

- Load file sampel positif yang disimpan dalam ekstensi .mat kemudian pilih alamat bounding box dalam tabel.

- Tentukan folder untuk sampel negatif yang disimpan sebelumnya. Selanjutnya gambar negatif ini akan di simpan ke dalam ImageDatastore.

- Langkah selanjutnya adalah training sampel positif dan sampel negatif tersebut dengan menggunakan cascade classifier object detector. Pada tahap inilah akan dipilih jenis ekstraksi fitur digunakan. Tahap ini dilakukan dua kali yaitu menggunakan ekstraksi fitur HOG dan Haar.

- Tahap train object detector membutuhkan waktu yang cukup lama untuk melakukan pelatihan objek. Setelah selesai di train maka hasilnya disimpan dalam database.

- Database Pola Lebar Kendaraan

Database ini memuat informasi tentang pola sampel positif bentuk lebar kendaraan dari arah belakang serta pola negatif sembarang gambar tanpa objek kendaraan yang telah dilatih menggunakan cascade classifier object detector. Setelah selesai proses latih maka secara otomatis hasilnya akan tersimpan ke dalam database dengan ekstensi .xml pada matlab.

\section{- Rekognisi Mobil}

Pada tahap ini sistem akan melakukan deteksi terhadap objek kendaraan sesuai dengan database train yang telah dilakukan. Proses perhitungan seberapa banyak kendaraan yang terdeteksi benar dan seberapa banyak salah deteksi akan di validasi menggunakan confusion matrix. 


\section{- Cascade Detector}

Pada tahap ini sistem akan melakukan uji data video baru berdasarkan data latih sebelumnya. Sistem akan di uji menggunakan HOG sebagai detektor latih.

- Tampilkan Hasil Estimasi Jarak

Tahap ini merupakan proses akhir dari sistem yang telah dibuat yaitu sistem secara otomatis akan menampilkan estimasi jarak kendaraan pada objek yang telah dideteksi sebelumnya. Hasil estimasi jarak tersebut nantinya akan divalidasi menggunakan Mean Squared Error (MSE).

- Load Kalibrasi Ukur Jarak

Kalibrasi ukur jarak merupakan proses pengukuran jarak antara kendaraan pada piksel frame disesuaikan dengan jarak sebenarnya yang telah di ukur secara manual. Proses ini berguna sebagai penentu estimasi jarak selanjutnya untuk proses testing.

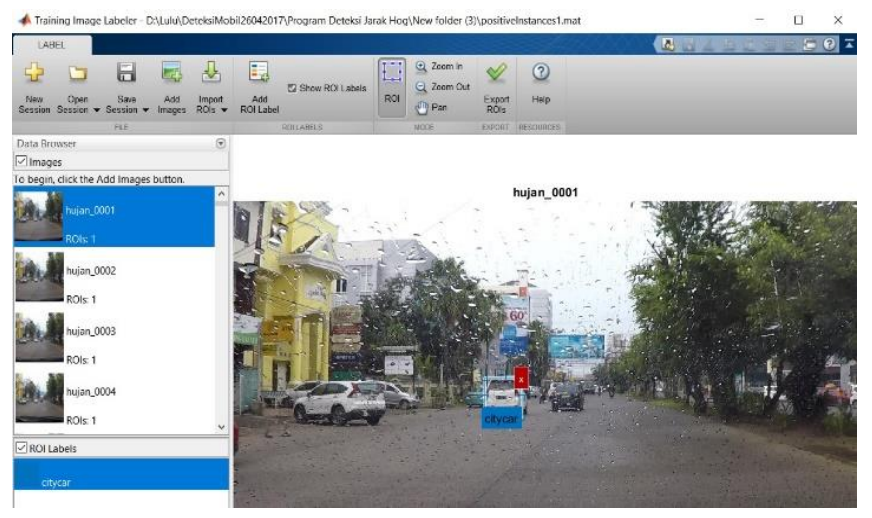

Gambar 9. Pemilihan ROI

\section{Hasil Penelitian}

\subsection{Validasi Deteksi Kendaraan}

Teknik pengujian pada data video menggunakan sampling 30 frame karena deteksi kendaraan dilakukan tiap 1 detik. Hasil deteksi di dapatkan dari Confusion Matrix menggunakan persamaan (3).

Tabel 1 dan Tabel 2 merupakan hasil perhitungan persentase TPR dan waktu komputasi yang dibutuhkan metode HOG untuk mendeteksi kendaraan jenis city car pada Tabel 1 dan jenis van pada Tabel 2. Pada Tabel 1 persentase TPR menggunakan metode HOG untuk city car menunjukkan hasil yang sangat baik dengan rata- rata TPR sebesar 92\% untuk 5 video yang diuji. Selain itu time processing yang dibutuhkan oleh metode $\mathrm{HOG}$ dalam 5 video rata-rata mencapai 77,32 $s$ atau 15,46 s per 30 frame dalam video.

Pada Tabel 2 persentase TPR menggunakan metode HOG untuk van menunjukkan hasil yang cukup baik dengan rata-rata TPR sebesar $64 \%$ untuk 5 video yang di uji. Selain itu time processing yang dibutuhkan oleh metode $\mathrm{HOG}$ dalam 5 buah video rata-rata mencapai 66,073 $s$ atau 13,21 $s$ per 30 frame dalam video.

Dari hasil TPR pada Tabel 1 dan Tabel 2 menunjukkan bahwa metode HOG pada penelitian ini bekerja lebih baik untuk jenis mobil city car dibandingkan dengan mobil van. Tetapi untuk time processing, waktu yang dibutuhkan untuk mengolah data mobil jenis city car jauh lebih lama dibandingkan dengan mobil van.

\subsection{Validasi Estimasi Jarak Relatif antara Kendaraan}

Hasil estimasi jarak relatif antara kendaraan yang didapatkan dari program yang dibuat, dibandingkan dengan jarak pengukuran kendaraan sebenarnya yang diukur secara manual menggunakan marker yang telah diberi pada badan jalan. Rumus (1) dan (2) digunakan untuk mendapatkan jarak relatif antar kendaraan dimasukkan ke dalam program yang telah dibuat.

Hasil pengukuran jarak relatif antar kendaraan untuk jenis mobil city car dan van dapat dilihat pada Tabel 3 dan 4 .

Tabel 1. Hasil persentase TPR dan time processing untuk mobil jenis city car

\begin{tabular}{ccc}
\hline Video & TPR & Time \\
\hline 1 & 100 & 76,573 \\
2 & 80 & 77,802 \\
3 & 80 & 74,730 \\
4 & 100 & 77,395 \\
\hline
\end{tabular}

Tabel 2. Hasil persentase TPR dan time processing untuk mobil jenis van

\begin{tabular}{ccc}
\hline Video & TPR & Time \\
\hline 1 & 80 & 70,956 \\
2 & 60 & 54,753 \\
3 & 50 & 62,085 \\
4 & 80 & 75,270 \\
\hline
\end{tabular}


Tabel 3. Hasil pengukuran estimasi jarak relatif pada jenis mobil city car

\begin{tabular}{ccccc}
\hline Data & $\begin{array}{c}\text { Jarak } \\
\text { Real }(\boldsymbol{m})\end{array}$ & $\begin{array}{c}\text { Estimasi } \\
\text { Jarak } \\
(\boldsymbol{m})\end{array}$ & Error & $\begin{array}{c}\text { Square } \\
\text { Error }\end{array}$ \\
\hline $\mathbf{1}$ & 5 & 5.55 & -0.55 & 0 \\
$\mathbf{2}$ & 6 & 6.07 & -0.07 & 0 \\
$\mathbf{3}$ & 7 & 7.04 & -0.04 & 0 \\
$\mathbf{4}$ & 8 & 7.53 & 0.47 & 0 \\
$\mathbf{5}$ & 9 & 8.71 & 0.29 & 0 \\
$\mathbf{6}$ & 10 & 9.44 & 0.56 & 0 \\
$\mathbf{7}$ & 11 & 10.47 & 0.53 & 0 \\
$\mathbf{8}$ & 12 & 11.2 & 0.8 & 1 \\
$\mathbf{9}$ & 13 & 13.5 & -0.5 & 0 \\
$\mathbf{1 0}$ & 14 & 13.01 & 0.99 & 1 \\
$\mathbf{1 1}$ & 15 & 14.59 & 0.41 & 0 \\
\hline MSE & & & & $\mathbf{0 . 2 9 5}$ \\
\hline
\end{tabular}

Tabel 4. Hasil pengukuran estimasi jarak relatif pada jenis mobil van

\begin{tabular}{ccccc}
\hline Data & $\begin{array}{c}\text { Jarak } \\
\text { Real } \\
(\mathbf{m})\end{array}$ & $\begin{array}{c}\text { Estimasi } \\
\text { Jarak } \\
(\boldsymbol{m})\end{array}$ & Error & $\begin{array}{c}\text { Square } \\
\text { Error }\end{array}$ \\
\hline $\mathbf{1}$ & 5 & 4.99 & 0.01 & 0 \\
$\mathbf{2}$ & 6 & 5.94 & 0.06 & 0 \\
$\mathbf{3}$ & 7 & 6.73 & 0.27 & 0 \\
$\mathbf{4}$ & 8 & 7.93 & 0.07 & 0 \\
$\mathbf{5}$ & 9 & 8.61 & 0.39 & 0 \\
$\mathbf{6}$ & 10 & 9.94 & 0.06 & 0 \\
$\mathbf{7}$ & 11 & 10.54 & 0.46 & 0 \\
$\mathbf{8}$ & 12 & 11.08 & 0.92 & 1 \\
$\mathbf{9}$ & 13 & 11.53 & 1.47 & 2 \\
$\mathbf{1 0}$ & 14 & 12.91 & 1.09 & 1 \\
$\mathbf{1 1}$ & 15 & 13.81 & 1.19 & 1 \\
\hline MSE & & & & $\mathbf{0 . 5 5 1}$ \\
\hline
\end{tabular}

Tabel 3 merupakan hasil estimasi jarak relatif antara kendaran untuk jenis mobil city car. Hasil yang didapatkan menunjukkan nilai yang sangat baik dengan MSE 0,29. Sehingga hasilnya dapat digunakan sebagai sistem pada konsep pengendara tanpa awak untuk menjaga mobil tetap aman dan terhindar dari terjadinya tabrakan.

Untuk Tabel 4 yang merupakan hasil estimasi jarak relatif antara kendaran untuk jenis mobil van. Hasil yang didapatkan menunjukkan nilai yang tidak terlalu baik dengan MSE 0,55. Sehingga hasilnya dapat digunakan karena nilainya mendekati 0 .

\section{Kesimpulan}

Berdasarkan hasil penelitian yang telah dilakukan, menunjukkan bahwa metode HOG sangat baik dalam mendeteksi objek kendaraan terutama untuk jenis mobil city car dengan ratarata persentase TPR sebesar $92 \%$ untuk 5 video yang di uji. Selain itu time processing yang dibutuhkan oleh metode HOG dalam 5 buah video rata-rata mencapai $77,32 s$ atau $15,46 s$ per 30 frame dalam video. Sedangkan untuk mobil jenis van, metode HOG mendapatkan rata-rata persentase TPR 64\% untuk 5 video yang di uji.

Selain itu time processing yang dibutuhkan oleh metode HOG dalam 5 buah video rata-rata mencapai 66,07 $s$ atau 13,21 $s$ per 30 frame dalam video. Untuk hasil estimasi jarak relatif antara kendaraan, metode width based yang digunakan untuk jenis mobil city car menunjukkan hasil yang lebih baik dengan nilai MSE 0,29 dan untuk mobil jenis van dengan nilai MSE 0,55.

\section{Referensi}

[1] Gaikindo, "2018, Sektor Otomotif Berpeluang Melaju," Indonesia, 03-May-2018.

[2] Kemenperin, "Kemenperin Bidik Industri Tumbuh 5,6 Persen Tahun 2018," 11-Dec-2017.

[3] Evan Hirsh, John Jullens, Reid Wilk, and Akshay Singh, "2016 Auto Industry Trends," 2016.

[4] U. Ozguner, C. Stiller, and K. Redmill, "Systems for Safety and Autonomous Behavior in Cars: The DARPA Grand Challenge Experience," Proc. IEEE, vol. 95, no. 2, pp. 397-412, Feb. 2007.

[5] Erico Guizzo, "How Google's Self-Driving Car Works," 18-Oct-2011.

[6] T. M. Hayath, Shenaz Begum, Usman K, and Naveen Kumar G, "A Novel Review on Google Driverless Autonomous Vehicle," Int. J. Adv. Sci. Res. Eng., 2017.

[7] Elvina Nawaguna, "Ford teams with Stanford, MIT to research automated driving," Reuters, United State, 22Jan-2014.

[8] Joann Muller, "No Hands, No Feet: My Unnerving Ride in Google's Driverless Car," Forbes, 21-Mar-2013. [Online]. Available:

https://www.forbes.com/sites/joannmuller/2013/03/21/n o-hands-no-feet-my-unnerving-ride-in-googlesdriverless-car/. [Accessed: 24-May-2018].

[9] Lee Gomes, "Hidden Obstacles for Google's SelfDriving Cars," MIT Technology Review, 28-Aug-2014. 
[10] L. A. Rentería, C. Torre-Ferrero, M. I. Arenado, and J. M. P. Oria, "Monovision-based vehicle detection, distance and relative speed measurement in urban traffic," IET Intell. Transp. Syst., vol. 8, no. 8, pp. 655664, Dec. 2014.

[11] J. Joseph Antony and Dr. M. Suchetha, "Vision Based Vehicle Detection: A Literature Review," Int. J. Appl. Eng. Res., vol. 11, pp. 3128-3133, 2016.

[12] Nurul Fathanah Mustamin, "Relative distance measurement between moving vehicles for manless driving," presented at the Isemantic, Semarang, 2017, pp. $1-4$.

[13]Ari Kurniawan and Marzuki Syahfirin, "Aplikasi Deteksi Objek Menggunakan Histogram of Oriented
Gradient Untuk Modul Sistem Cerdas Pada Robot Nao." Researchgate, 2016.

[14]N. Dalal and B. Triggs, "Histograms of Oriented Gradients for Human Detection,” 2005, vol. 1, pp. 886893.

[15] Adrian Rosebrock, "Find distance from camera to object/marker using Python and OpenCV," PyImageSearch, 19-Jan-2015.

[16] Tantri Indrabulan, "Perbandingan Metode Deteksi Objek Berbasis Video untuk Survei Arus Lalu Lintas," Universitas Hasanuddin, Makassar, 2016.

[17] S. Hansun, "Jakarta Stock Exchange (JKSE) forecasting using fuzzy time series," 2013, pp. 130-134. 